\title{
Photo-Oxygenation of Trans Anethole
}

\author{
A. Mahmoud Dawidar \\ Chem. Dept., Fac. of Sci., \\ Mansoura University \\ Mansoura, Egypt
}

\author{
Kh. Hussien \\ Chem. Dept., Fac. of Sci., \\ Mansoura University \\ Mansoura, Egypt
}

\author{
M. Mahmoud Abou-Elzahab \\ Chem. Dept., Fac. of Sci., \\ Mansoura University \\ Mansoura, Egypt
}

\author{
M. El-Hoseiny Mostafa \\ Chem. Dept., Fac. of Sci., \\ Mansoura University \\ Mansoura, Egypt
}

\author{
M. Abdel-Mogib \\ Chem. Dept., Fac. of Sci., \\ Mansoura University \\ Mansoura, Egypt
}

\begin{abstract}
Photo-oxygenation of trans anethole (1), the main constituent of anise essential oil, using tetraphenylporphyrine (TPP) as a singlet oxygen sensitizer in chloroform gave 4-methoxybenzaldehyde ( $p$-anisaldhyde) (2), 2-(4-methoxyphenyl)propan-2-ol (3) as well as erythro and threo 1-(4-methoxyphenyl)propane-1,2-diol (4a, 4b). The structures of the photo-oxygenation products were elucidated by spectral means.
\end{abstract}

Keywords: Photo-oxygenation, anethole, tetraphenylporphyrine, 4-methoxybenzaldehyde, 2-(4-methoxyphenyl)propan2-ol, 1-(4-methoxyphenyl)propan-1,2-diol.

\section{INTRODUCTION}

Essential oils play an important role in our life because of their therapeutic activities and various applications in food industries. Essential oils are mixtures of various components like shikimates, mono-and sesquiterpenoids. The unsaturated essential oil compounds are easily oxidized, upon exposure to light, air and enhanced by temperature [1].

Photo-oxygenation reactions were carried out by several workers on some authentic individual monoterpenes, which occur frequently as major constituents of essential oils. We found that photooxygenation of essential oils has improved their biological activities [2].

The biological activities of trans anethole, as the main constituent of aniseed oil, before and after photooxygenation, including free radical scavenging, antimicrobial, deoxy ribonucleic acid (DNA) and protein cleaving, in addition to their hypoglycaemic effect were studied by Dawidar et al.,2008 [2].

Anise oil is obtained from the seeds of Pimpinella anisum L. (Umbeliferae). Its major constituent is transanethole (more than 60\%) [1].

Schantz and Juvonen, 1969, reported that transanethole is autoxidized to its $\beta$ - glycol, the amount of which increased initially during storage but decreased thereafter on further autoxidation via anisaldhyde to polymer. Thus the quality of aniseed oil depends on the presence or absence of the degradative oxidation products [3].

Garnero and Roustan, 1979, reported that transanethole undergoes a serious photo-rections as photoisomerization, photooxidation and photodimerization. Products as anisaldhyde, anise ketone, and anisic acid, are oxygenation products of trans anethole [4]. Lewis and Kojima, 1988, studied the mechanism of the photoisomerization, dimerization and oxygenation of trans- and cis anethole in terms of the role of monomer and dimer cation radicals [5]. Greer et al., 2000, reported on the effects of the added acid to the reaction of singlet oxygen with trans anethole. They suggested a new mechanism that invokes a proton transfer from methanol and benzoic acid to the formed perepoxide and Zwitter intermediates [6].

Mang et al., 2007, optimized a biocatalytic single-step alkene cleavage for aryl alkene compounds. They employed trans anethole as a model substrate, using hydrogen peroxide as an oxidizing agent. The products were identified as anisaldhyde and acetaldehyde [7]. Elgendy and Khayyat, 2008, performed photochemical oxidation of trans anethole using hydrogen peroxide where the corresponding epoxy derivatives together with 4-methoxybenzaldhyde were identified. They found that thermal oxidation of trans anethole with 3chloroperoxybezoic acid at room temperature resulted in formation of dimeric epoxide, 2,5-bis(4methoxyphenyl)-3,6-dimethyl-1,4-dioxin as the only product. Photo-oxygenation of trans anethole in the presence of tetraphenylporphyrine, Rose Bengal, or chlorophyll as sensitizers has led to a mixture of 1-(4methoxyphenyl)prop-2-en-1-yl hydroperoxide and 4methoxybenzaldhyde [8].

We reported here the identified photo-oxygenation products of trans-anethole using molecular oxygen. 


\section{EXPERIMENTAL}

\subsection{Materials:}

TPP was obtained from Fluka Company. trans anethole was supplied by Sigma Company. Photo-oxygenation apparatus consists of sodium lamp (Phillips G/5812 SON), cylindrical jar $(15 \mathrm{w} \times 201 \times 30 \mathrm{~h} \mathrm{~cm})$ filled with ethanol, sample tube which was inserted in the jar, and cooling unit with alcoholic thermometer. Dry oxygen was supplied from external cylinder. Distance between sodium lamp and sample tube was $10 \mathrm{~cm}$.

\subsection{General procedure for photo- oxygenation:}

A solution of trans anethole $(1 \mathrm{ml})$ in chloroform (50 $\mathrm{ml}$ ) and a few mgs of tetraphenylporphyrine (TPP) was irradiated for $24 \mathrm{hrs}$. using the described apparatus. The solvent was evaporated at $20^{\circ} \mathrm{C} / 0.1$ torr to give an oily material. The crude photooxygenation products were separated on silica gel column using petroleum ether $\left(60-80^{\circ} \mathrm{C}\right)$ as eluent to remove the sensitizer. The excess of trans anethole was eluted by petroleum ether: ethyl acetate (9:1). The photo products were eluted by petroleum ether: ethyl acetate (3:2), and separated by preparative TLC.

\section{4-methoxybenzaldehyde anisaldhyde) (2)}

Colour: Pale yellow oil, UV, $\lambda_{\max }$ (ethanolic solution), nm: 276, 287; IR, v, (oil film), $\mathrm{cm}^{-1}$ : 3020 (C-H, aromatic, str.), 2949, $2866\left(\mathrm{CH}_{3}\right.$ aliphatic and $\mathrm{C}-\mathrm{H}$ aldehydic), 1690 (carbonyl group), $1590 \quad(\mathrm{C}=\mathrm{C}$ aromatic), 1530 ( $\mathrm{C}=\mathrm{C}$ aliphatic); EIMS, $\mathrm{m} / \mathrm{z}$ (rel. int.): $136\left[\mathrm{M}^{+}\right](45)$ corresponding to $\mathrm{C}_{8} \mathrm{H}_{8} \mathrm{O}_{2}, 135\left[\mathrm{M}^{+}-\mathrm{H}\right]$ (100), $107\left[\mathrm{M}^{+}-\mathrm{CHO}\right]$ (30), $92\left[\mathrm{M}^{+}-\mathrm{CH}_{3} \& \mathrm{CHO}\right](30)$, 77[ $\left.\mathrm{M}^{+}-\mathrm{OCH}_{3} \& \mathrm{CHO}\right](70) ;{ }^{1} \mathrm{H}-\mathrm{NMR}(300 \mathrm{MHz}$,

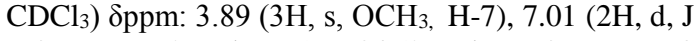
$=8.7 \mathrm{~Hz}, \mathrm{H}-2$ and $\mathrm{H}-6), 7.84(2 \mathrm{H}, \mathrm{d}, \mathrm{J}=8.7 \mathrm{~Hz}, \mathrm{H}-3$ and $\mathrm{H}-5), 9.89(1 \mathrm{H}, \mathrm{s}, \mathrm{CHO}, \mathrm{H}-8)$.

\section{2-(4-methoxyphenyl)propan-2-ol (3)}

Colour: Light yellow oil, UV, $\lambda_{\max }$ (ethanolic solution), nm: 249, 315; IR, $v$, (oil film), $\mathrm{cm}^{-1}: 3443$ (broad band, OH group), 3052 (C-H, aromatic, str.), 2969, 2934 $\left(\mathrm{CH}_{3}\right.$ aliphatic), 1380, 1020, and 938; ${ }^{1} \mathrm{H}-\mathrm{NMR}$ (400 $\left.\mathrm{MHz}, \mathrm{CDCl}_{3}\right) \delta \mathrm{ppm}: 1.25\left(6 \mathrm{H}, \mathrm{s}, 2 \mathrm{CH}_{3}\right), 3.88(3 \mathrm{H}, \mathrm{s}$, $\left.\mathrm{OCH}_{3}\right), 6.70(1 \mathrm{H}, \mathrm{s}, \mathrm{OH}), 6.95(2 \mathrm{H}, \mathrm{d}, \mathrm{J}=8 \mathrm{~Hz}, \mathrm{H}-3, \mathrm{H}-$ 5), $8.04(2 \mathrm{H}, \mathrm{d}, \mathrm{J}=8 \mathrm{~Hz}, \mathrm{H}-2, \mathrm{H}-6)$; EIMS, m/z (rel. int.): $166\left[\mathrm{M}^{+}\right](0.5), 165\left[\mathrm{M}^{+}-1\right](14), 149\left[\mathrm{M}^{+}-\mathrm{OH}\right]$ (89), $148\left[\mathrm{M}^{+}-\mathrm{H}_{2} \mathrm{O}\right](13), 135\left[\mathrm{M}^{+}-\mathrm{OCH}_{3}\right]$ (49), 107 $\left[\mathrm{M}^{+}-\mathrm{C}_{3} \mathrm{H}_{7} \mathrm{O}\right](10), 76\left[\mathrm{M}^{+}-\mathrm{OCH}_{3} \& \mathrm{C}_{3} \mathrm{H}_{7} \mathrm{O}\right](22), 71$ (59), 70 (30), 69 (50), 57 (100).

\section{1-(4-methoxyphenyl)propane-1,2-diol (4a, 4b) (2:1 molar ratio)}

Colour: Light yellow oil, UV, $\lambda_{\max }$ (ethanolic solution), nm: 269, 282; IR, v, (oil film), $\mathrm{cm}^{-1}: 3450-3500$ (broad band, $\mathrm{OH}$ group), 3062, 3027(C-H, aromatic, str.), 2954, 2925, $2856 \quad\left(\mathrm{CH}_{3}\right.$ aliphatic $), 1600 \quad((\mathrm{C}=\mathrm{C}$ aromatic), 1450, 1070, and 1027; ${ }^{1} \mathrm{H}-\mathrm{NMR}(300 \mathrm{MHz}$, $\left.\mathrm{CDCl}_{3}\right) \delta \mathrm{ppm}(4 \mathrm{a}): 1.05(3 \mathrm{H}, \mathrm{d}, \mathrm{J}=6.6 \mathrm{~Hz}, \mathrm{H}-10 \mathrm{a})$, 1.750 (1H, br.s, OH), 2.62 (1H, br.s, $\mathrm{OH}), 3.82(3 \mathrm{H}, \mathrm{s}$, $\left.\mathrm{OCH}_{3}\right), 3.84(1 \mathrm{H}, \mathrm{m}, \mathrm{H}-9 \mathrm{a}), 4.33(1 \mathrm{H}, \mathrm{d}, \mathrm{J}=7.8 \mathrm{~Hz}$, at C-8a), 6.89 (2H, d, J= 8.7 Hz, H-2a, H-6a), 7.29 (2H, d, $\mathrm{J}=7.8 \mathrm{~Hz}, \mathrm{H}-3 \mathrm{a}, \mathrm{H}-5 \mathrm{a}) ;{ }^{1} \mathrm{H}-\mathrm{NMR}\left(300 \mathrm{MHz}, \mathrm{CDCl}_{3}\right) \delta$ ppm (4b) : $1.11(3 \mathrm{H}, \mathrm{d}, \mathrm{J}=6.6 \mathrm{~Hz}, \mathrm{H}-10 \mathrm{~b}), 1.75(1 \mathrm{H}$, br.s, $\mathrm{OH}), 2.62(1 \mathrm{H}$, br.s, $\mathrm{OH}), 3.82\left(3 \mathrm{H}, \mathrm{s}, \mathrm{OCH}_{3}\right), 4.00$ (1H, m, H-9b), 4.60 (1H, d, J = 7.8 Hz, H-8b), $6.89(2 \mathrm{H}$, d, J = 8.7 Hz, H-2b, H-6b), 7.29 (2H, d, J = 7.8 Hz, H3b, H-5b); EIMS m/z (rel.int.): $182\left[\mathrm{M}^{+}\right]$(3), $167\left[\mathrm{M}^{+}-\right.$ $\left.\mathrm{CH}_{3}\right]$ (6), 151[ $\left.\mathrm{M}^{+}-\mathrm{OCH}_{3}\right](4), 148\left[\mathrm{M}^{+}-2 \mathrm{OH}\right]$ (28) 164 $\left[\mathrm{M}^{+}-\mathrm{H}_{2} \mathrm{O}\right]$ (5), $137\left[\mathrm{M}^{+}-\mathrm{H}_{2} \mathrm{O} \& \mathrm{C}_{2} \mathrm{H}_{4}\right]$ (82), 136 (10), 135 (22), 133 (5), 109 (28), $107\left[\mathrm{M}^{+}-\mathrm{C}_{3} \mathrm{H}_{7} \mathrm{O}_{2}\right]$ (10), 97 (36), 85 (51), 84 (25), 83 (68), 81 (28), 71 (57), 69 (65), 57 (100), 54 (78).

\section{RESULTS AND DISCUSSIONS}

The reaction was carried out in $\mathrm{CHCl}_{3}$, in the presence of tetraphenylporphyrine (TPP) as a singlet oxygen sensitizer at $-20^{\circ} \mathrm{C}$ for $24 \mathrm{hrs}$. The resulting mixture was separated to three products identified as 4methoxybenzaldehyde ( $p$-anisaldhyde) (2), 2-(4methoxyphenyl)propan-2-ol (3) and erythro and threo 1-(4-methoxyphenyl)propane-1,2-diol (4a, 4b).

The IR spectrum of (2) showed the carbonyl absorption band at $1690 \mathrm{~cm}^{-1}$. Its ${ }^{1} \mathrm{H}-\mathrm{NMR}$ spectrum revealed the presence of a singlet at $\delta 9.89 \mathrm{ppm}$, characteristic for the aldehydic proton and signals of $p$-disubstitued benzene (AA'BB' spin system at $\delta 7.84 \mathrm{ppm}$ with coupling constant $8.7 \mathrm{~Hz}$ ). Additionally, the spectrum showed the methoxyl protons at $\delta 3.89 \mathrm{ppm}$ as a singlet. The mass spectrum of (2) indicated a $\mathrm{M}^{+}$at $\mathrm{m} / \mathrm{z} 136$ (45\%) corresponding to the molecular formula $\mathrm{C}_{8} \mathrm{H}_{8} \mathrm{O}_{2}$, and a base peak at m/z $135(100 \%)$ due to $\left[\mathrm{M}^{+}-\mathrm{H}\right]$.

The ${ }^{1} \mathrm{H}$-NMR spectrum of (3) showed a $p$-disubstitued benzene (AA'BB' spin system at $\delta 8.04$ and $6.95 \mathrm{ppm}$ with coupling constant $8 \mathrm{~Hz}$ ), two methoxyl and hydroxyl protons singlets at $\delta 3.88$ and $6.70 \mathrm{ppm}$, respectively. This is in addition to a singlet of six protons at $\delta 1.25 \mathrm{ppm}$ which was assigned to a dimethyl carbinol group. The mass spectrum of (3) showed ion peaks due to $[\mathrm{M}-\mathrm{OH}],\left[\mathrm{M}-\mathrm{H}_{2} \mathrm{O}\right],\left[\mathrm{M}-\mathrm{OCH}_{3}\right]$, [M$\left.\mathrm{C}_{3} \mathrm{H}_{7} \mathrm{O}\right]$ at $\mathrm{m} / \mathrm{z} 149,148,135$, and 107 respectively. 
International Journal of Science and Engineering Applications Volume 4 Issue 5, 2015, ISSN-2319-7560 (Online)

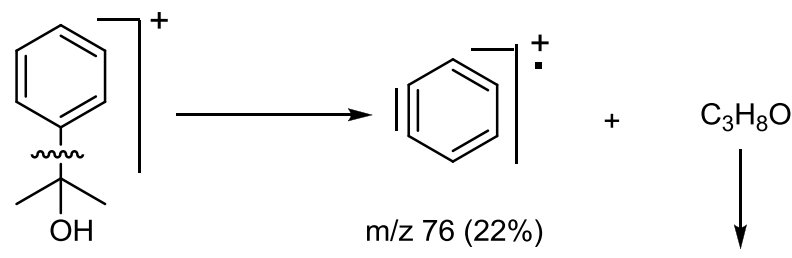

$\mathrm{m} / \mathrm{z} 135(49 \%)$
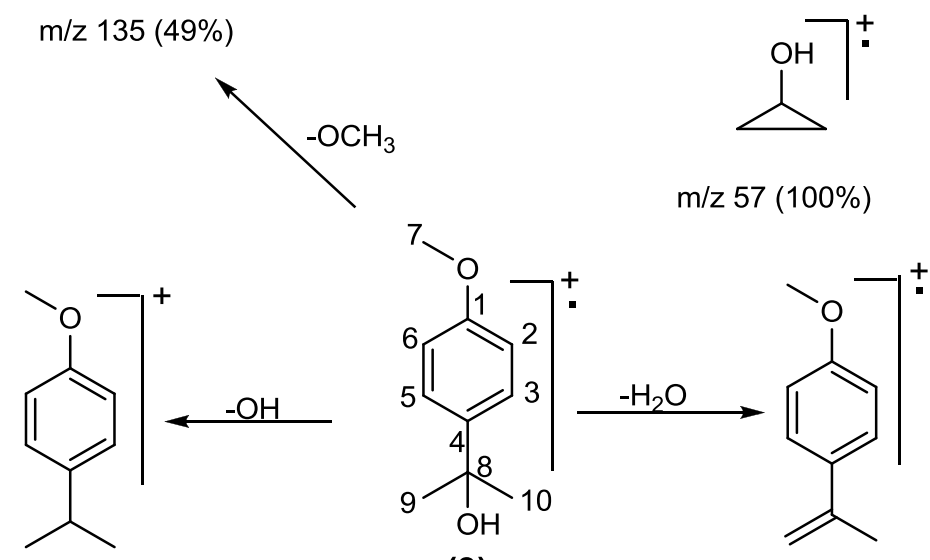

$\mathrm{m} / \mathrm{z} 149(89 \%)$

(3)

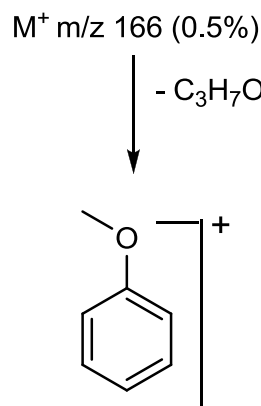

$\mathrm{m} / \mathrm{z} 107(10 \%)$

\section{A proposed fragmentation pattern of 3}

Products $(\mathbf{4 a}, \mathbf{b})$ as a mixture were identified as erythro and threo 1-(4-methoxyphenyl)propan-1,2-diol. The IR spectrum revealed the presence of hydroxyl groups, due to the absorption broad band at $3450-3500 \mathrm{~cm}^{-1}$. ${ }^{1} \mathrm{H}-$ NMR spectrum showed $p$-disubstitued benzene (AA'BB' spin system at $\delta 7.29$ and $\delta 6.89 \mathrm{ppm}$ with coupling constant 8.7 ). The spectrum also showed a singlet at $\delta 3.82 \mathrm{ppm}$ for the methoxyl groups. Protons of methyl groups in positions $\mathrm{C}-10 \mathrm{a}$ and $\mathrm{C}-10 \mathrm{~b}$ gave the characteristic doublets at $\delta 1.05$ and $1.11 \mathrm{ppm}$ with coupling constant $6.6 \mathrm{~Hz}$, whereas protons at $8 \mathrm{a}$ and $8 \mathrm{~b}$ showed two doublets at $\delta 4.33$ and $4.60 \mathrm{ppm}$ with coupling constant $7.8 \mathrm{~Hz}$ for both. Protons at C-9a and C-9b appeared as multiplets at $\delta 3.84$ and $4.00 \mathrm{ppm}$, respectively. Protons of hydroxyl groups were viewed at $\delta 1.75$ and $2.62 \mathrm{ppm}$. The mass spectrum showed a molecular ion peak $\mathrm{M}^{+}$at $\mathrm{m} / \mathrm{z} 182(3 \%)$ corresponding to the molecular formula $\mathrm{C}_{10} \mathrm{H}_{14} \mathrm{O}_{3}$. 
International Journal of Science and Engineering Applications Volume 4 Issue 5, 2015, ISSN-2319-7560 (Online)

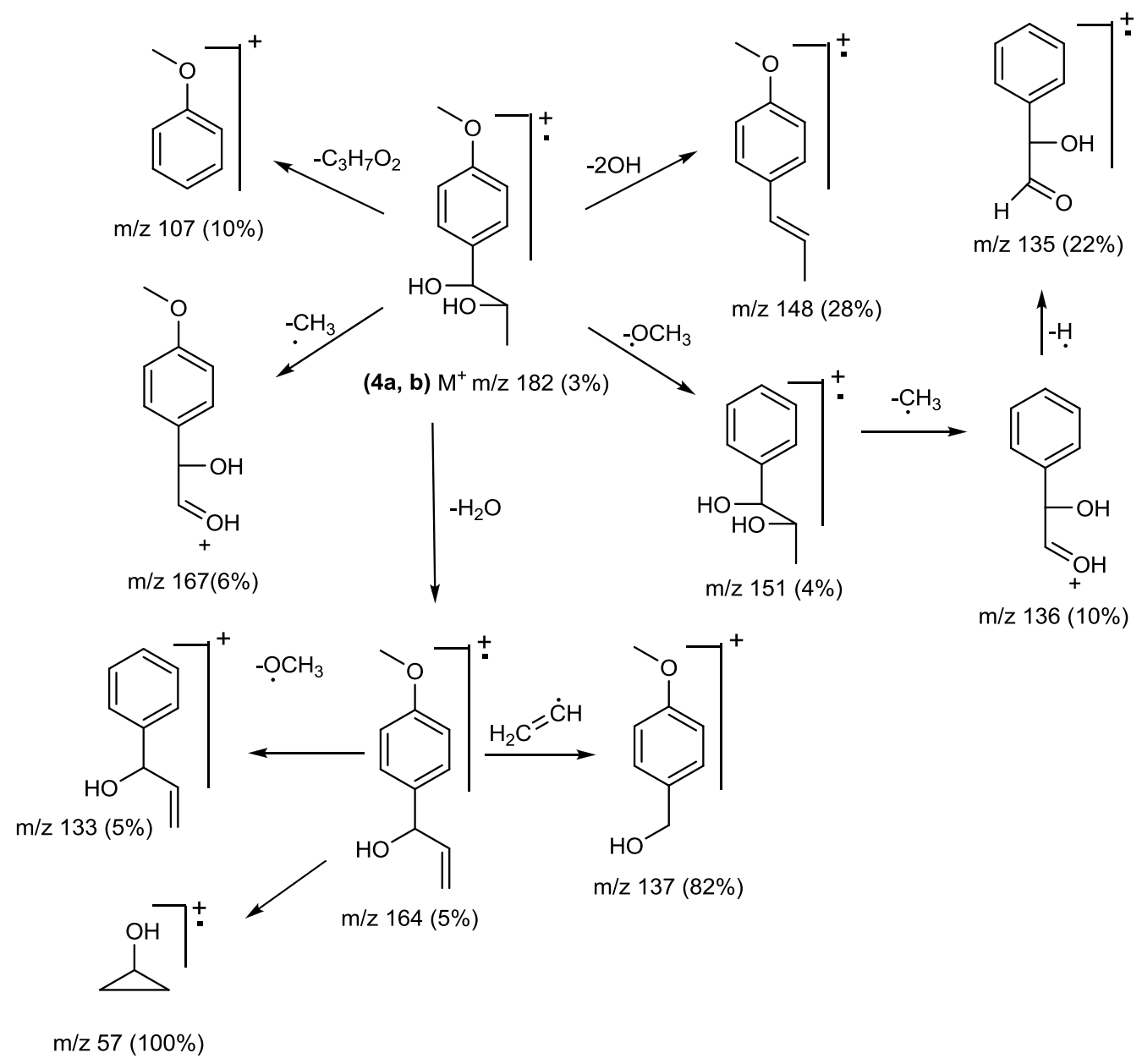

A proposed fragmentation pattern of $4 a$ and $4 b$

A probable formation of $p$-anisaldhyde (2) and the glycols 4a, 4b may be through the dioxetane intermediate. Whereas, the photo product (3) may be obtained through 1, 2 carbon shift followed by singlet oxygen attack in the protic solvents. 
International Journal of Science and Engineering Applications

Volume 4 Issue 5, 2015, ISSN-2319-7560 (Online)

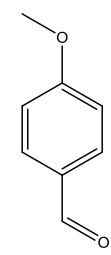

(2)

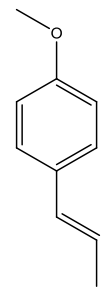

(E)-1-methoxy-4-(prop-1-enyl)benzene (1)

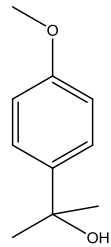

(3)

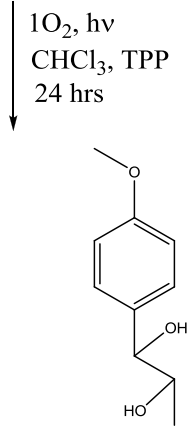

(4a)

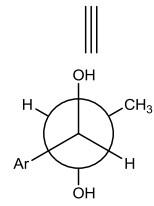

threo

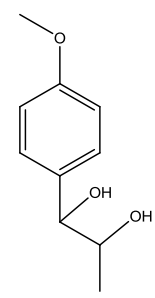

(4b)

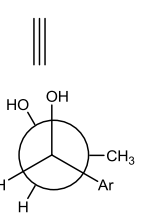

enthero

Scheme 1: Photo-oxygenation of trans anethole (1)

\section{REFERENCES}

[1] Dawidar, A. M.; Hussien, Kh. (2010), Essential oils composition, photooxidation, bioactivity, Osiris, Cairo, Egypt.

[2] Dawidar, A. M.; Abdel Mogib, M.; El-Ghorab, A. H.; Mahfouz, M.; Elsaid, F. G.; Hussien, Kh. (2008), Chemical composition and effect of photooxygenation on biological activities of Egyptian commercial anise and fennel essential oils, Journal of Essential Oil-Bearing Plants, vol. 11 issue (2), pp 124-136.

[3] Schantz, M. V.; Juvonen, S. (1969), Arch. Pharm., vol. 302 issue (10), pp 775-787.

[4] Garnero, J.; Roustan, J. (1979), Labo-pharma-Probl. Tech. vol. 27 issue (288), pp 542-548.

[5] Lewis, F. D.; Kojima, M. (1988) Electron Transfer Induced Photoisomerization, Dimerization, and Oxygenation of trans- and cis-Anethole. The Role of Monomer and Dimer Cation Radicals. J. Am. Chem. Soc., vol. 110, pp 8664-8670.

[6] Greer, A.; Vassilikogiannakis, G.; Lee, K.; Koffas, T. S.; Nahm, K.; Foote, C. S. (2000) Reaction of Singlet Oxygen with trans-4-Propenylanisole. Formation of [2+2] Products with Added Acid. J. Org. Chem., vol. 65 issue (21), pp 6876-6878.

[7] Mang, H.; Gross, J.; Lara, M.; Goessler, C.; Schoemaker, H. E.; Guebitz, G. M.; Kroutil, W. (2007) Optimization of a biocatalytic single-step alkene cleavage of aryl alkenes. Tetrahedron vol. 63, pp 3350-3354.

[8] Elgendy, E. M.; Khayyat, S. A. (2008), Oxidation reactions of some natural volatile aromatic compounds: anethole and eugenol, Russian Journal of Organic Chemistry, vol. 44 issue (6), pp 823-829. 